\title{
UPAYA MENINGKATKAN KEMAMPUAN MEMBACA UNTUK REFERENSI DALAM TEKS BAHASA INGGRIS SISWA KELAS VII-1 SMP MUHAMMADIYAH PALANGKA RAYA MELALUI METODE INFERENCE
}

\author{
Effort to Improving Reading Ability for Reference in English at SMP Muhammadiyah \\ Palangka Raya Students Class VII-1 through Inference Method
}

\author{
*Tri Waluyo \\ English Teacher, Muhammadiyah Palangkaraya Junior High School, RTA Milono St. Km.1,5 \\ Palangka Raya, Indonesia \\ *e-mail : mas tri waluyo@yahoo.co.id
}

\begin{abstract}
ABSTRAK
Penelitian Tindakan Kelas ini dilatarbelakangi oleh kemampuan membaca reading for reference dari 23 siswa kelas VII1 yang rendah yang skor rata-rata 7 pada rentang 0-100. Penelitian ini bertujuan untuk mengetahui; (1) peningkatan kemampuan siswa kelas VII-1 SMP Muhammadiyah Palangka Raya 2015-2016 dalam membaca reading for reference, (2) Peningkatan nilai hasil belajar siswa kelas VII-1 2015-2016 secara individu dan kalsikal dalam membaca reading for refernce dan (3) Peningkatan jumlah siswa kelas VII-1 SMP Muhammadiyah palangka Raya 2015-2016 yang mencapai Kriteria Ketuntasan Minimal. Penelitian tindakan kelas ini menerapkan teknik inference dengan langkah-langkah; siswa menemukan makna kata yang maknanya tersirat dengan menerjemahkannya ke dalam bahasa Indonesia secara kontekstual, kemudian mencari rujukan kata dengan mengubah kalimat yang terdapat kata yang dirujuk tersebut menjadi kalimat tanya dengan menambah kata tanya siapa atau apa. Setelah dua siklus, hasil penelitian tindakan kelas ini menunjukan bahwa ; (1) Peninkatan rata-rata secara individu terendah sebesar 1,5 kali atau $150 \%$ dan tertinggi 8,5 kali lipat atau $850 \%$, (2) Peningkatan rata-rata secara klasikal setelah dua siklus mencapai 5 kali lipat (500\%) dan (3) Jumlah siswa yang mencapai Kriteria Ketuntasan Minimal meingkat dari 0\% menjadi 60,9\%. Ini menunjukan bahwa tekhnik inference cukup berhasil meningkatkan jumlah siswa dalam mencapai KKM.
\end{abstract}

Kata kunci: Peningkatan, Membaca untuk Referensi, Metode Inference

\begin{abstract}
This Classroom Action Research is backgrounded by the average of the students' ability in English reading for refence of the 23 seventh grade students are low. Those are 7 (seven) in the range of $0-100$. This study is aimed to know ; (1) the improvement of the SMP Muhammadiyah Palangka Raya seventh grade students 'ability in reading for reference during semester 2 in the academic year of 2015-2016, (2) the improvement of individual or classical achievement score averagelly in reading for refence, and (3) The improvement of the number of students reach the passing grade score. This study is applied the inference technique, and the steps are; Finding the contextual meaning to the words, which are infered, by translating into the Indonesian language, Then infering the meaning the words which are infered by changing the sentences contain the words into questions using "who or what". After implementing 2 cycles, the findings of this study are; (1). The lowest improvement of individual achievement score in reading for reference averagely about 1.5 times or $150 \%$ and the highest is 8.5 times or $850 \%$. Classically, the students' ability in reading for reference is to be 5 times or $500 \%$ improved, and (3) The total number of the students who reach the passing score grade is improved from $0 \%$ tobe $60.9 \%$. This shows that inference can increase the students in achieveing passing grade in reading for reference.
\end{abstract}

Keywords: Improvement, Reading for Reference, Inference Method

PENDAHULUAN

Peraturan Menteri Pendidikan Nasional No 23

Tahun 2006 tentang Standar Kompetensi Lulusan

Satuan Pendidikan Dasar dan Menengah, menyatakan bahwa untuk mata pelajaran Bahasa Inggris, Kompetensi yang diharapkan adalah kompetensi berkomunikasi yang direalisasikan melalui empat keterampilan berbahasa yaitu 
mendengar, berbicara, membaca dan menulis. Tetapi dari hasil pengamatan dan penilaian keterampilan membaca siswa, khususnya siswa di kelas VII-1 SMP Muhammadiyah Palangka Raya, Kailmantan Tengah tahun pelajaran 2015-2016, mereka masih mengalami kesulitan dan kelemahan untuk mengerti isi bacaan maupun informasi dalam bacaan. Kesulitan terbesar adalah membaca reference atau reading for reference meskipun terdapat siswa telah menerima mata pelajaran Bahasa Inggris sejak mereka berada di Sekolah Dasar, dan mempelajarinya dengan alokasi waktu yang lebih banyak di SMP.

Dari hasil evaluasi diri dan refleksi hasil pembelajaran, terlihat bahwa penguasaan menjawab pertanyaan refence siswa kurang cukup. Dari pre test yang dilaksanakan untuk mengukur ketrampilan membaca reference bagi kelas VII-1, ternyata tidak ada siswa yang mampu menjawab seluruh soal reference dengan benar Penyebabnya antara lain adalah guru kurang mengembangkan model pembelajaran secara maksimal untuk meningkatkan penguasaan siswa dalam menjawab pertanyaan refence khususnya dalam membaca reading for reference yang terkait dengan kata ganti orang atau dalam bahasa Inggris dikenal sebagai personal pronoun.

Berdasarkan kenyataan tersebut, maka sangat diperlukan upaya peningkatan keterampilan membaca siswa dengan pengembangan kemampuan membaca reading for reference mereka melalui model pembelajaran yang menggunakan tekhnik inferensi atau dalam penelitian ini dikenal juga sebagai inferring atau inference agar memudahkan mereka memahami isi dan berbagai informasi bacaan reading for reference. Dengan menggunakan tekhnik inference / inferensi diharapkan akan dapat meningkatkan kemampuan siswa dalam menjawab pertanyaan refence. Beberapa pertanyaan refence kadang-kadang begitu abstrak bagi siswa dan sesuatu yang abstrak sangat sulit untuk dipelajari apalagi diingat oleh siswa.

Penelitian ini ditujukan untuk mengetahui: (1) Peningkatan kemampuan siswa kelas VII-1 SMP Muhammadiyah Palangka Raya 2015/2016 dalam membaca reading for reference, (2). Peningkatan nilai hasil belajar siswa kelas VII-1 SMP Muhammadiyah Palangka Raya 2015/2016 secara individu dan klasikal dalam membaca reading for reference setelah mengikuti pembelajaran dengan menggunakan tekhnik inference, dan (3). Peningkatan jumlah siswa kelas VII-1 SMP Muhammadiyah Palangka Raya 2015/2016 yang mencapai KKM.

Menurut Lattulipe dalam Marsiyah (2009) yang dikutip Kartika Wulandari dalam aspect of reading comprehension menyatakan sebagai berikut: reference is the words or phrases that is used either before or after the reference in the reading material. They are used to avoid unnecessary repetition of words or phrases. It means that such words are used to be a signal to the reader to find the meaning elsewhere in the text or sometimes is called pronoun.

For example: Once upon a time, there was a beautiful girl called Cinderella. She lived with her stepsister and stepmother. They were very bossy. She had to do all the housework. What does the word "they" in the sentence refer to? The word "they" refers to her stepsister and stepmother. The word "they" is called reference because it becomes pronoun to "her stepsister and stepmother". 
Berdasarkan pengertian tersebut membaca reference atau reading for reference dapat diartikan sebagai tindakan mencari acuan atau rujukan kepada sesuatu atau seseorang atas kata ganti atau dalam bahasa Inggris disebut pronoun dalam bacaan. Sebagaimana disebutkan dalam penggalan bacaan cinderela di atas, kata "they" disebut reference karena kata tersebut merupakan kata ganti dari kata stepsister dan stepmother.

Sedang yang dimaksud Inference atau dalam peneltian ini juga disebut inferensi berasal dari bahasa Inggris inference dan dari bahasa latin in (dalam) dan ferre (membawa) (Lorens, 2002:349). Lebih lanjut terdapat beberapa pengertian inferensi sebagai berikut (1) proses logis atau konseptual dalam menarik makna dari satu pernyataan atau lebih; (2) simpulan yang dicapai; (3) deduksi atau menarik suatu simpulan dari premis-premis yang diterima; (4) induksi, menarik suatu kesimpulan dari pernyataan-pernyataan faktual yang diambil sebagai evidensi bagi kesimpulan.

Teknik inferensi tampaknya merupakan tekhnik menemukan makna dalam teks. Untuk memahaminya siswa perlu menemukan makna yang hendak dicari atau dalam bahasa Inggris dengan cara menerjemahkannya terlebih dahulu kemudian menemukan makna sesuai dengan kontek kalimatnya karena inferensi dapat berarti sebagai proses yang dilakukan pembaca untuk memahami makna yang tidak diungkapkan secara tersurat. Setelah memahami makna sesuai dengan konteks kalimatnya maka siswa dapat mengubah kalimat yang kata atau ungkapannya akan dicarikan rujukannya dengan kata tanya siapa atau apa.

\section{METODOLOGI}

Dalam penelitian ini peneliti menggunakan pendekatan kualitatif naturalistik. Subyek penelitian akan diamati secara langsung ketika sedang mengikuti proses pembelajaran di kelas. Kemudian akan diikuti dengan interview terhadap beberapa subyek yang dianggap layak datanya. Kedua langkah ini akan menghasilkan data kualitatif. Selanjutnya peneliti juga akan melihat hasil ulangan harian siswa untuk mengetahui sejauh mana pencapaian KKM mata pelajaran Bahasa Inggris oleh siswa setelah mengikuti pembelajaran membaca yang dilakukan oleh guru dengan menggunakan tekhnik inference. Data kualitatif akan menjadi data tambahan atas data kuantitatif tentang siswa yang mendapatkan nilai tuntas dan siswa mana yang mendapatkan nilai tidak tuntas.

Teknik analisis data kualitatif ini akan dianalisis dengan prosedur sebagai berikut : (1) Reduksi Data yakni Menurunkan data dari hasil observasi, in-depth interview, dan hasil ulangan formatif, kemudian memilah-milah data berdasar kategorisasi yang diambil dari observasi, interview dan hasil ulangan formatif. (2) Display data dengan melakukan tabulasi data yaitu kategori yang akan digunakan untuk tabulasi data sesuai dengan hasil observasi, interview dan ketuntasan nilai siswa (tuntas/tidak tuntas). Karena hanya 23 siswa yang diteliti, tabulasi data diharapkan mencermin individu dan klasikal. Dan (3) Pengambilan keputusan / drawing decision Pengambilan simpulan dari tabulasi data yang menggambarkan berapa siswa yang aktif, dan berapa siswa yang tidak aktif. Berapa siswa yang nilainya tuntas dan berapa yang tidak tuntas, dan seterusnya. 
Arifin (2009 : 298) menyatakan bahwa untuk memperoleh informasi mengenai keberhasilan proses belajar peserta didik, guru dapat menggunakan berbagai teknik, seperti mengamati keaktifan siswa dalam belajar baik secara perseoarngan maupun dalam kelompok, melakukan wawancara tentang kesulitan yang dihadapi peserta didik, memberikan tes formatif dan lainnya. Guru juga harus menetapkan criteria apa yang akan digunakan untuk menentukan keberhasilan peserta didik. Keberhasilan siswa dapat disusun berdasarkan tingkatan tertentu seperti sangat kurang, kurang, cukup, baik dan sangat baik atau juga sangat aktif, aktif, cukup aktif dan kurang aktif.

Berdasarkan penjelasan Arifin diatas, tampaknya keberhasilan pembelajaran dapat dilihat pada partisipasi aktif siswa dan hasil belajar peserta didik. Oleh karena itu penelitian ini menggunakan dua indikator yang digunakan untuk menyatakan keberhasilan meningkatkan kemampuan siswa SMP Muhammadiyah Palangka Raya kelas VII-1 yaitu jika ; (1) Data kuantitaif menunjukan bahwa lebih dari $50 \%$ siswa yang secara aktif mengikuti pembelajaran memperoleh nilai hasil belajar sebesar 70 atau lebih, dan (2) Data kuantitatif menunjukan perbaikan nilai siswa pada akhir siklus jika dibandingkan dengan kemampuan awal setelah mengikuti pembelajaran dengan menggunakan kriteria yang dikembangkan berdasarkan panduan penilaian Sekolah Menengah Pertama yang disebagai beterbitkan oleh Direktorat Pembinaan SMP tahun 2015 sebagai berikut:
Tabel 1. Panduan perkembangan kemampuan belajar

\begin{tabular}{|c|c|c|}
\hline NO & $\begin{array}{c}\text { Persentase } \\
\text { Perkembangan } \\
\text { Kemampuan } \\
\text { dibanding } \\
\text { Kemampuan Awal }\end{array}$ & Predikat \\
\hline 1. & $86-\geq 100 \%$ & Berhasil dengan Sangat Baik \\
2 & $71-85 \%$ & Berhasil dengan Baik \\
3. & $56-70 \%$ & Cukup Berhasil \\
4. & $\leq 55 \%$ & Kurang Berhasil \\
\hline
\end{tabular}

\section{HASIL DAN PEMBAHASAN}

Pada permulaan atau pra penelitian, peneliti perlu memastikan mengapa perlu diadakan perbaikan kemampuan siswa dalam membaca reference, oleh karena itu diperlukan data awal yang menggambarkan kemampuan awal siswa. Untuk itu peneliti mengadakan test awal dengan materi dan hasil sebagai berikut.

Assalamu'alaikum and Morning everybody, I would like to tell us about one of my family. Do you know who she is? Of course you do not know. Well everybody listen to me, I would like to tell us about my mother. Her name is Anna. You know, my mother is a beautiful person. She is not tall but not short. She has long-curlyblack hair. Her eyes are like honey. Her skin is like brown. She has beautiful smile.

My mother is a very kind person. She is very lovely, friendly and patient. She loves to help people. I love my mother because she is hospitality. She kisses me when I will go anywhere. She helps her children to solve her problems.

She is a good wife and also a good mother. She always takes care of her family. She likes our house clean and organized. She is puts everything in the right place. She does not like messes.

It's about my mother. Thank you. Bye

1. "Her" in the $3^{\text {rd }}$ line refers to ....

2. "She" in $4^{\text {th }}$ line refers to .... 
3. "She" in the $6^{\text {th }}$ line refers to ....

4. "Her" in the $9^{\text {th }}$ line refers to ....

5. "She "in line 12 th refers to ....

Hasil test awal dapat terlihat seperti tabel berikut.

Tabel 2. Kemampuan awal siswa

\begin{tabular}{|c|l|c|}
\hline No & \multicolumn{1}{|c|}{ Nama } & Nilai \\
\hline 1 & AR & 0 \\
\hline 2 & AP & 0 \\
\hline 3 & DI & 20 \\
\hline 4 & DP & 0 \\
\hline 5 & EK & 0 \\
\hline 6 & FA & 0 \\
\hline 7 & GV & 20 \\
\hline 8 & HJ & 0 \\
\hline 9 & IT & 0 \\
\hline 10 & IH & 0 \\
\hline 11 & IS & 80 \\
\hline 12 & LT & 0 \\
\hline 13 & MH & 20 \\
\hline 14 & MM & 0 \\
\hline 15 & MQ & 0 \\
\hline 16 & MF & 0 \\
\hline 17 & MF & 0 \\
\hline 18 & MR & 20 \\
\hline 19 & NA & 0 \\
\hline 20 & SD & 20 \\
\hline 21 & SD & 0 \\
\hline 22 & SY & \\
\hline 23 & ZA & \\
\hline Rata-Rata & \\
\hline & & 0 \\
\hline
\end{tabular}

Kemudian peneliti mengadakan perbaikan dengan menerapkan tekhnik inference dengan langkahlangkah sebagai berikut;

Pada kegiatan pembelajaran siklus I dan 2 relatif sama dengan langkah-langkah berikut : guru membagikan teks deskriptif ragam lisan kepada siswa. Kemudian secara berpasangan, para siswa menggarisbawahi dan membahas kata sulit yang digunakan dalam teks. Dalam membahas kosa kata siswa menggunakan pendukung berupa kamus dan sumber lain yang relevan. Membahas dan mengembangkan kosakata tata bahasa, noun, verb, pronoun .. Membahas struktur atau ciriciri teks ragam lisan.

Pada tahap berikutnya, siswa, secara berpasangan, berlatih mengungkapkan makna dalam teks deskriptif dengan teknik inferensi atau dengan mengadakan inferring atau inference atau inferensi kata ganti yang terdapat dalam teks. Dalam tahap ini guru berperan sebagai fasilitator dan sumber belajar karena pada saat ini guru menjelaskan dan melatih siswa menggunakan tekhnik inferensi untuk mengungkapkan makna sebagaimana dalam kajian teoritis dilanjutkan tahapan para siswa menjawab pertanyaan terkait dengan reference dan diakhiri dengan bersama guru dan siswa memeriksa jawaban hasil inferring atau inference atau inferensi. Hasil Pembelajaran selama siklus 1 dan 2 sebagai berikut:

Gambar 1. Progress Report Hasil Belajar Individu Siswa dari Siklus ke Siklus

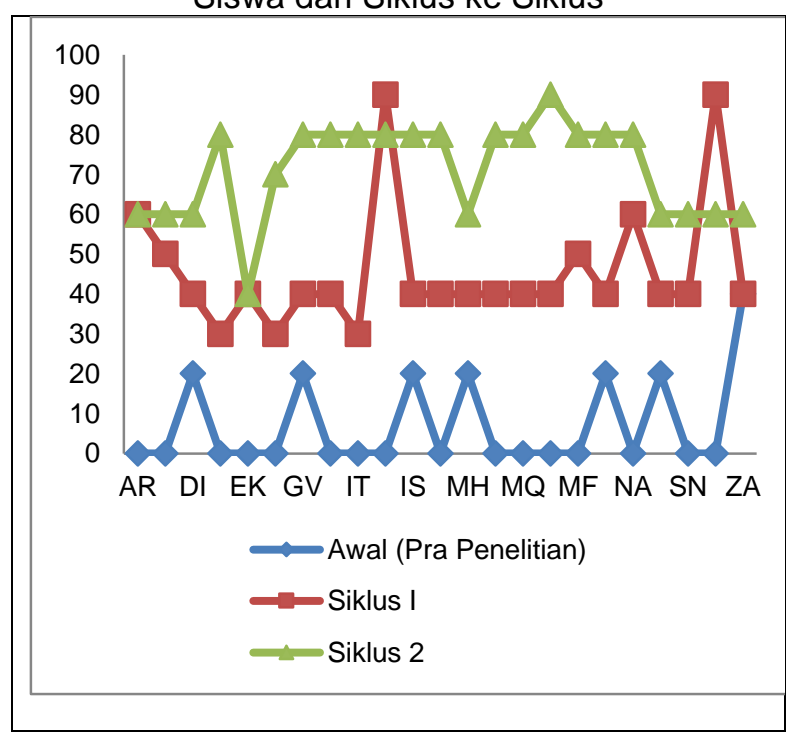


Gambar 2. Progress Report Peningkatan Rerata dari Siklus ke Siklus

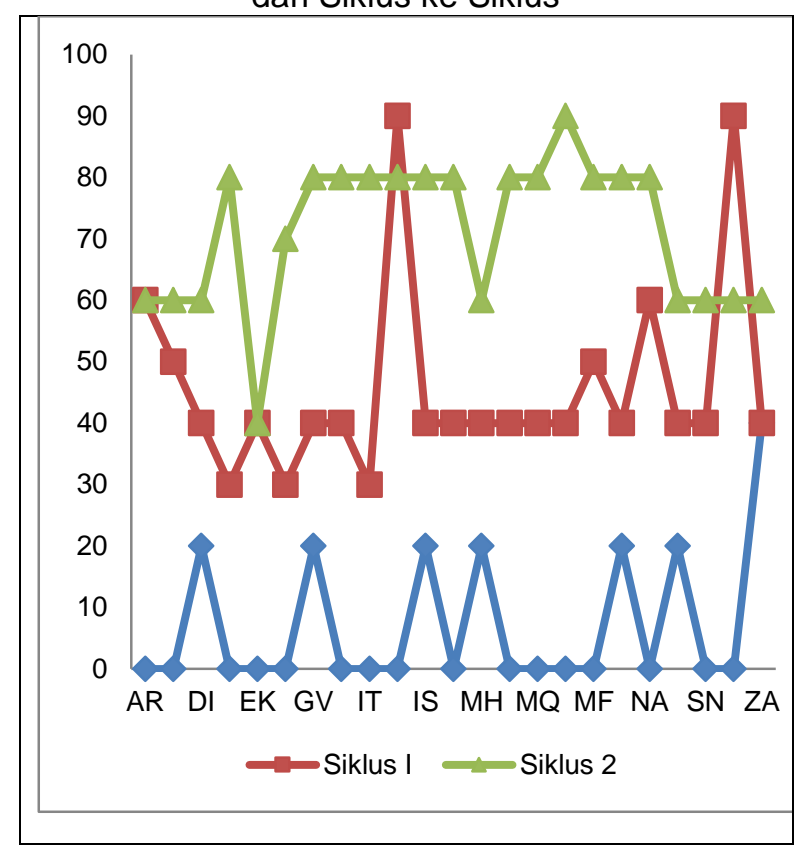

Gambar 3. Jumlah Siswa berdasrkan Perolehan Nilai dari Siklus ke Siklus

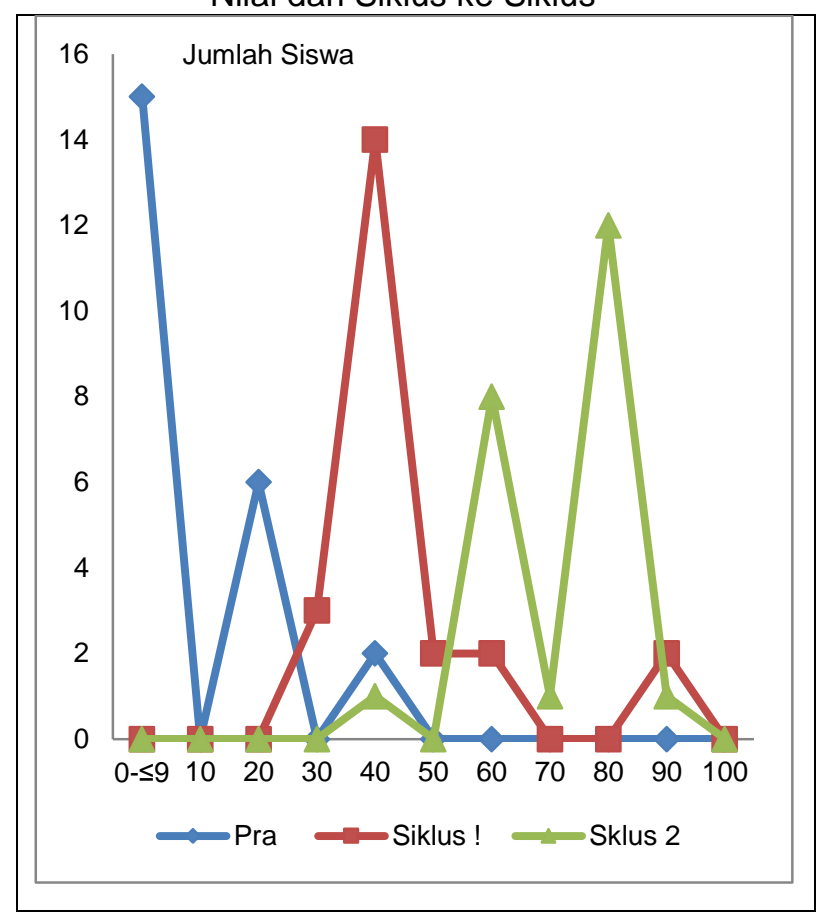

Gambar 4. Progress Report rerata peningkatan kemampuan membaca reading for reference selama dua siklus secara individu dan klasikal

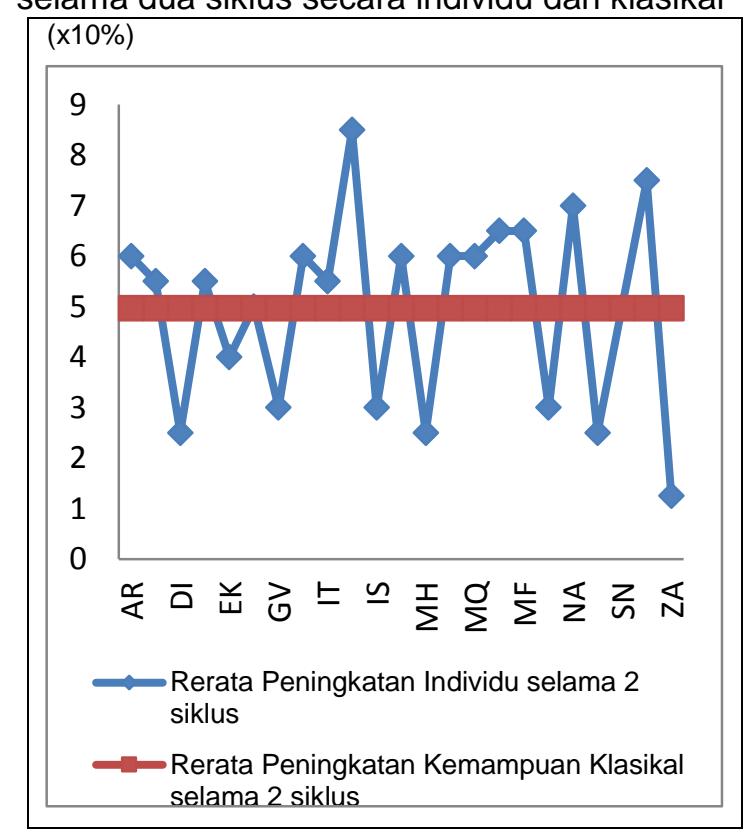

Gambar 5. Progress Report Rerata Peningkatan Kemampuan Membaca Reading for Reference selama dua siklus secara Individu dan Klasikal

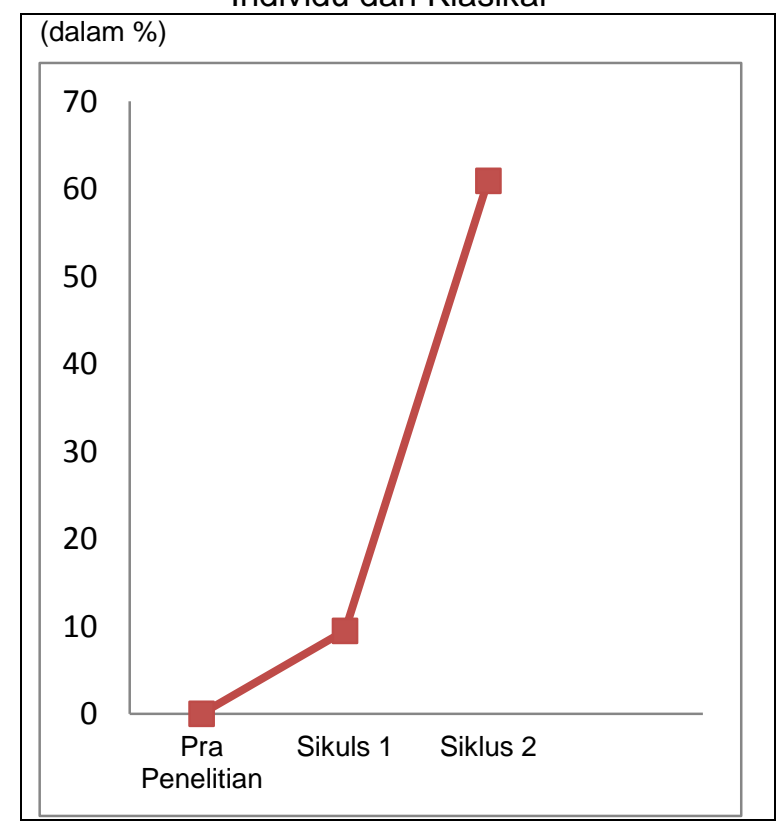

Nilai kemampuan awal siswa sebagian besar berada pada nilai 0 dengan nilai tertinggi 40 . Pada siklus satu kemampuan siswa seluruhnya meningkat dengan sebagian besar berada di 
kisaran pada nilai 40 dengan nilai tertinggi 90 . Kemudian pada siklus ke 2 nilai siswa juga meningkat dimana sebagian besar berada pada nilai 80 dengan tertinggi pada nilai 90 . Hal tersebut terlihat pada grafik.3.

Nilai siswa dalam membaca reading for reference siklus 1 secara umum berada di atas kemampuan awal pada pra penelitian dan begitu juga nilai siswa dalam membaca reading for reference siklus 2 juga meningkat. Hal itu tampak bahwa nilai siswa pada siklus tersebut berada di atas nilai siklus 1 sebagaimana tampak pada Gambar 1. Gambar 1 di atas juga menunjukan bahwa trend kemampuan siswa selalu meningkat dari siklus ke siklus

Nilai kemampuan yang dimiliki oleh sebagian besar siswa dalam membaca reading for reference pada awal atau pada saat pra penelitian dalam rentang 0-100 adalah dibawah sepuluh dimana menempati grafik tertinggi dengan jumlah 12 siswa. Tertinggi ke dua dengan jumlah siswa 6 adalah nilai 20 dan yang ketiga adalah nilai 40 dengan jumlah siswa yang memperolehnya sebanyak 2 orang siswa. Artinya adalah sebagian besar siswa memperoleh nilai dibawah 10.

Pada siklus 1 sebagaimana Gambar 3 nilai tertinggi ditempati nilai 40 . Ini berarti bahwa jumlah siswa terbanyak memperoleh nilai 40 , disusul nilai enam puluh dengan jumlah siswa 6 , ketiga nilai 30 dengan jumlah siswa 3, ke empat adalah nilai 50 dengan jumlah siswa 2 dan begitu juga nilai 90 . Gambar 3 juga menunjukan bahwa pada siklus ke 2, jumlah siswa terbanyak adalah siswa yang memperoleh nilai 80 dimana ditunjukan dengan grafik tertinggi dengan jumlah 12 orang, disusul jumlah siswa yang memperoleh nilai 60 yaitu sebanyak 8 orang dan yang terakhir adalah jumlah siswa yang memperoleh nilai 40 dan 90 dengan jumlah siswa masing-masing 1 orang.

Peningkatan rerata secara individu dan klasikal juga tampak pada Gambar 4. Gambar 4 tersebut menunjukan bahwa peningkatan rerata terendah secara individu terjadi pada ZA yaitu 1,5 kali dari kemampuan awal dan tertinggi pada siswa berrinisial IH dengan peningkatan sebesar 8,5 kali lipat. Peningkatan rerata kemampuan secara klasikal juga terjadi. Gambar 4 menunjukan rerata peningkatan kemampuan siswa stelah dua siklus menjcapai rerata 5 kali lipat.

Peningkatan juga terjadi pada prosetase jumlah siswa yang mencapai atau melampaui KKM. Gambar 5 Memperlihatkan bahwa pada kemampuan awal tidak ada satupun siswa yang mencapai KKM karena pada $0 \%$. Pada siklus 1 meningkat menjadi 9,5\% dan pada akhir siklus 2 jumlah siswa yang mencapai atau melampaui KKM sebanyak 60,9\%.

\section{KESIMPULAN}

Berdasarkan pembahasan hasil penelitian di atas dapat disimpulkan bahwa setelah penerapan teknik inference atau dalam penelitian ini dengan nama lain inferring atau inferennsi selama 2 (dua) siklus dapat disimpulkan bahawa : (1). Hasil penelitian memperlihatkan bahwa teknik tersebut dapat meningkatkan kemampuan siswa dalam membaca reading for reference. (2) Secara individu terjadi peningkatan dalam rentang 1,5-8,5 kali lipat sedangkan rerata kemampuan secara klasikal siklus 1 da 2 terjadi peningkatan sebesar rerata 5 kali lipat atau $500 \%$. Ini menunjukan bahwa teknik inference mampu meningkatkan kemampuan secara individu dan kalsikal secara sangat baik. (3). Jumlah siswa yang mencapai atau 
melampaui KKM juga meningkat dari $0 \%$ pada pra penelitian meningkat menjadi 9,5\% (Sembilan koma lima persen) siklus 1 , dan pada akhir siklus 2 jumlah siswa yang mencapai atau melampaui KKM sebanyak 60,9 \%.(enam puluh koma sembilan persen). Ini menunjukan bahwa teknik inference cukup berhasil meningkatkan jumlah siwa dalam mencapai KKM

\section{DAFTAR PUSTAKA}

Agustien. 2005. Materi Pelatihan Terintegrasi. Bahasa Inggris. Jakarta: Depdiknas

Arifin, Z. 2009. Evaluasi Pembelajaran. Bandung : PT Remaja Rodakarya

Brown, D.H. 2000. Teaching by Principles An Interactive Approach to Language Pedagogy. Second Edition. California: Longman

Depdiknas. 2004. Kurikulum Tingkat Satuan Pendidikan untuk SMP/MTs

Handayani, D.S.N. 2010. The Effectiveness of Nursery Rhymes in Teaching Speaking to the Eighth Grade Students of SMP Muhamadiyah 1 Alternatif Kota Magelang in the School year 2010/2011 (A Paper). Magelang: Tidar University Magelang

McNeil, J.D. 1991. Reading Comprehensiitonon $3^{r d}$ E. New York: Harper Collins Publisher

Raymond, S.P. 2003. Principles of Teaching. Associate Professor of Education Bloomsburg University. Bloomsburg. HTML Document

Suryati, N. 2003. Pembelajaran Membaca Bahasa Inggris. Jakarta : Departemen Pendidikan Nasional.

Susilowati, Y. 2007. Upaya Peningkatan Ketrampilan Berbahasa Produktif Siswa pada Teks Recount Melalui Biografi Card Trading (Laporan Penelitian Tindakan). Ungaran
Thornbury, S. 2004. How to Teach Vocabulary. Malaysia, Longman

Trimo. 2007. Artikel PTK: Sebuah Refleksi Pembangkitan Profesionalisme Guru. Dimuat tanggal 22 Desember 2007 